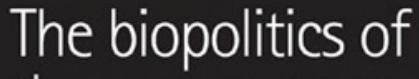
the war on terror Life struggles, liberal modernity and the defence of logistical societies

Julian Reid 


\section{The biopolitics of the war on terror}

\section{MANCHESTER \\ 1824}

Manchester University Press 


\section{Simon Tormey and Jon Simons · series editors}

The times we live in are troubling, and as always theory struggles to keep pace with events in its efforts to analyse and assess society, culture and politics. Many of the 'contemporary' political theories emerged and developed in the twentieth century or earlier, but how well do they work at the start of the twenty-first century?

Reappraising the Political realigns political theory with its contemporary context. The series is interdisciplinary in approach, seeking new inspiration from both traditional sister disciplines, and from more recent neighbours such as literary theory and cultural studies. It encompasses an international range, recognising both the diffusion and adaptation of Western political thought in the rest of the world, and the impact of global processes and non-Western ideas on Western politics.

\section{already published}

Rehinking equality: the challenge of equal citizenship Chris Armstrong

Radical democracy: politics between abundance and lack Lars Tønder and Lasse Thomassen (eds) 


\section{THE BIOPOLITICS OF THE WAR ON TERROR}

Life struggles, liberal modernity, and the defence of logistical societies

Manchester University Press

Manchester and New York

distributed exclusively in the USA by Palgrave 
Copyright $\odot$ Julian Reid 2006

The right of Julian Reid to be identified as the author of this work has been asserted by him in accordance with the Copyright, Designs and Patents Act 1988.

Published by Manchester University Press

Oxford Road, Manchester M13 9NR, UK

and Room 400, 175 Fifth Avenue, New York, NY 10010, USA

www.manchesteruniversitypress.co.uk

Distributed exclusively in the USA by

Palgrave, 175 Fifth Avenue, New York,

NY 10010, USA

Distributed exclusively in Canada by

UBC Press, University of British Columbia, 2029 West Mall,

Vancouver, BC, Canada V6T 1Z2

British Library Cataloguing-in-Publication Data

A catalogue record for this book is available from the British Library

Library of Congress Cataloging-in-Publication Data applied for

ISBN 0719074053 hardback

EAN 9780719074059

First published 2006

$15141312111009080706 \quad 10987654321$

Typeset

by Action Publishing Technology Ltd, Gloucester

Printed in Great Britain

by Biddles Ltd, King's Lynn 